\title{
EFFECT OF ANIMAL SLURRY ON CARBON STRUCTURAL S235JR STEEL AT $318 \mathrm{~K}$
}

\author{
${ }^{1}$ Tomasz LIPIŃSKI, ${ }^{2}$ Dariusz KARPISZ \\ 1 University of Warmia and Mazury in Olsztyn, Poland EU, tomaszlipinski.tl@gmail.com \\ ${ }^{2}$ Cracow University of Technology, Poland, EU, dariusz.karpisz@pk.edu.pl
}

https://doi.org/10.37904/metal.2020.3569

\begin{abstract}
Carbon steels as a construction materials are still very popular, but exposed to corrosion. Low-carbon steel is often used as a construction material for agricultural equipment. Corrosion is a result of the chemical and electrochemical environment influence on the material. In alloys and metals changes occur as a result of interaction with the surrounding environment. One of the most important factors constructional material is corrosion resistance, first of all in demanding animal environment. Slurry is a mixture of animals dung and urine. The aggressive corrosive constituents in slurry are urea, uric acid, naturally excreted chloride and as well as ammonia or ammonium salts. In practice roughness parameters for every of the research times can be used for determine the size of steel corrosion. Equipment with carbon steel can be easy built by welding quickly at a low price, but biggest problem in aggressive environment is their corrosion protection. The purpose of this article is to investigate corrosion resistance in different time $(48,96,144,192,240,288,336,384$ hours) using weight loss and profile roughness parameters of structural steel in grade S235JR in natural animal slurry at $318 \mathrm{~K}$. Corrosion tests show that the tested steel in animal slurry as a corrosive environments is characterized through continuous corrosion process whose measure may be surface roughness.
\end{abstract}

Keywords: Steel, carbon steel, corrosion, corrosion rate, animal slurry

\section{INTRODUCTION}

Carbon steel is a popular material in the construction of machines and equipment for agricultural because is cheaper than more resistance but expensive stainless steel. The properties of low carbon steel are influence of different factors, including chemical composition, manufacturing technology, working conditions and other. The properties steel, are determined mostly by its microstructure. The structural low carbon steels have a ferritic-perlitic microstructure. The percentage of each microstructure phase shapes the properties of the steel. The main factor of properties with is microstructure depends on the manufacturing technology and heat treatments of steel. Corrosion resistance is one with more an important factor of the quality and application of structural steels. The S235JR low carb on steel is commonly used for agricultural industry. Apart of this negative corrosion effect have mostly other metals inclusions which are dependent on their shape, numbers, size and distribution. Corrosion processes are able to extract metal atoms from the metal lattice, which atoms during the process pass to corrosion products. Particularly dangerous is the corrosion causing local diffusion of metal atoms. The problem is huge because each with low-carbon structural steel is sensitive on corrosion. The corrosion rate first of all is depends of different environment.

The accumulation of chemical elements with animal slurry near steel is the primary cause of corrosion. The results of corrosion of low carbon steel in machines and equipment for agriculture are geometry change can cause construction cracking, building up and increments of corrosion products what can caused to withstand load effects of constructions materials [1-3]. Usually corrosion of carbon steel was identified during the maintenance process. Unfortunately, corrosive processes of carbon steel can cause different forms of corrosion. Many researches are conducted to evaluate the performance of carbon and stainless steel 
microstructures under a variety of corrosive conditions [4]. The wide variety of agricultural employed makes difficult to define where corrosion can be a little or most damaging. Corrosion in agricultural industry is also influenced by animal slurry and its products that have passed into the atmosphere such as chlorides vapors, $\mathrm{NO}_{x}\left(\mathrm{NO}_{2}, \mathrm{NO}_{3}\right), \mathrm{SO}_{y}\left(\mathrm{SO}_{2}, \mathrm{SO}_{4}\right)$, and $\mathrm{H}_{z} \mathrm{~S}$ where $\mathrm{S}$ is the acid residue $\left(\mathrm{H}_{2} \mathrm{~S}, \mathrm{H}_{2} \mathrm{SO}_{3}\right)$ and other. The $\mathrm{H}_{2} \mathrm{~S}$ is the most corrosive agent that dissolves in moisture films where it undergoes oxidation by aerobic bacteria to very agresive sulphuric acid $\mathrm{H}_{2} \mathrm{SO}_{4}$. Penetration corrosion processes of low carbon steel with animal products are very aggressive [5-7]. Slurry is a mixture of dung and urine, and farmyard manure and etc. The corrosive constituents in slurry are firs of all: ammonia and its salts, urea, uric acid, naturally excreted chloride. Consequence influence corrosion processes during the maintenance low carbon steel with animal slurry atmosphere can be atmosphere corrosion effect, too. The animal slurry is important corrosive environmental factors in agricultural industry. Having regard to the importance of the corrosion resistance for exploitation, this research was carried out to determination the corrosion resistance of low carbon structural steel in animal slurry. For intensification the corrosion process the samples was tested at temperature $318 \mathrm{~K}$ [8-9].

The obtained results may be interested for steel producers [10-12], biotechnology industry utilizing apparatus also working in aggressive environments [13-15] and for waste utilization branch [16,17]. The rate of destruction may be also of interest to data analysts i.a. in image analysis [18-20], temperature field modeling [21], statistical design of similar experiments [22], especially when associated with non-parametric uncertainty estimation [23-25]. Last but not least, it should be also taken into consideration in management systems [26-27].

\section{MATERIALS AND METHODS}

The research was performed on low carbon S235JR (1.0038) steel plate $t=5.00 \mathrm{~mm}$ thickness with chemical composition according to the EN 10025-2:2004 Hot rolled products of structural steels. The real chemical composition of the tested steel is presented in Table 1.

Table 1 Real mean chemical composition of the S235JR steel [wt. \%]

\begin{tabular}{|c|c|c|c|c|c|c|c|c|}
\hline $\mathbf{C}$ & $\mathbf{S i}$ & $\mathbf{M n}$ & $\mathbf{P}$ & $\mathbf{S}$ & $\mathbf{C r}$ & $\mathbf{C u}$ & $\mathbf{N i}$ & $\mathbf{N}$ \\
\hline 0.19 & 0.22 & 0.90 & 0.03 & 0.04 & 0.03 & 0.02 & 0.02 & 0.01 \\
\hline
\end{tabular}

The specimens from plate $t=5.00 \mathrm{~mm}$ thickness was cut mechanically samples to size $40 \times 10 \mathrm{~mm}$ (area of about $13 \mathrm{~cm}^{2}$ ). Next the samples were polished with water paper successively to $\mathrm{Ra}=0.32 \mu \mathrm{m}$, and cleaned by $95 \% \mathrm{C}_{2} \mathrm{H}_{5} \mathrm{OH}$. The samples despite the ferritic-perlitic microstructure were tested in accordance with the standard dedicated for stainless steel ISO 3651-1:1998 Determination of resistance to intergranular corrosion of stainless steels. The application of the criteria provided for stainless steel was intended to enable comparative assessment of the corrosion resistance of carbon steel and stainless steel in the future. Animal slurry mean chemical compositions and parameters as a corrosive media is presented in Table 2 [29]. The corrosion resistance steel was tested by measurement of loss in mass (Huey test).

The corrosion rate of S235JR steel measured in $\mathrm{mm}$ per year was calculated with the use of the below formula (1), measured in $\mathrm{g} \cdot \mathrm{m}^{-2}$ was calculated with the use the below formula (2):

$r_{\text {corm }}=\frac{8760 \cdot m}{S \cdot t \cdot \rho}$
$r_{\text {corg }}=\frac{10000 \cdot m}{S \cdot t}$

where:

$t$ - time of treatment in a corrosive solution of boiling nitric acid [hours],

$\mathrm{S}$ - surface area of the sample $\left[\mathrm{cm}^{2}\right]$, 


$$
\begin{aligned}
& \mathrm{m} \text { - average mass loss in boiling solution }[\mathrm{g}] \text {, } \\
& \rho \text { - sample density }\left[\mathrm{g} / \mathrm{cm}^{3}\right] \text {. }
\end{aligned}
$$

\begin{tabular}{|c|c|c|c|c|c|c|c|}
\hline $\mathbf{P}$ & $\mathrm{K}$ & Mg & $\mathrm{Ca}$ & $\mathrm{Na}$ & $\mathrm{Cu}$ & $\mathrm{Zn}$ & $\mathrm{NO}_{3}$ \\
\hline$(\mathrm{mg} / \mathrm{L})$ & $(\mathrm{mg} / \mathrm{L})$ & $(\mathrm{mg} / \mathrm{L})$ & $(\mathrm{mg} / \mathrm{L})$ & $(\mathrm{mg} / \mathrm{L})$ & $(\mathrm{mg} / \mathrm{L})$ & $(\mathrm{mg} / \mathrm{L})$ & $(\mathrm{mg} / \mathrm{L})$ \\
\hline 175 & 158 & 6.4 & 39.2 & 102 & 0.08 & 0.41 & 35 \\
\hline \multicolumn{2}{|c|}{ PH } & EC & \multicolumn{2}{|c|}{ BOD } & \multicolumn{2}{|l|}{ COD } & TKN \\
\hline & & $\left(\mathrm{mS} / \mathrm{cm}^{2}\right)$ & \multicolumn{2}{|c|}{$(\mathrm{mg} / \mathrm{L})$} & $(\mathrm{mg} / \mathrm{L})$ & \multicolumn{2}{|c|}{$(g / L)$} \\
\hline \multicolumn{2}{|c|}{6.7} & 5.86 & \multicolumn{2}{|c|}{2350} & 2980 & \multicolumn{2}{|c|}{1.82} \\
\hline
\end{tabular}

Table 2 Mean chemical compositions and parameters animal slurry

EC - electric conductivity, BOD Biochemical oxygen demand, COD - chemical oxygen demand, TKN - Total kjeldahl nitrogen

The influence of animal slurry on the S235JR carbon steel corrosion resistance was investigated using weight loss. The mass of samples were measured by Kern ALT 3104AM general laboratory precision balance with accuracy of measurement $0.0001 \mathrm{~g}$. The time range of research was: 48, 96, 144, 192, 240, 288, 336, 384 and 432 hours with accuracy of measurement 2 minutes.

Profile roughness parameters were analyzed according to the PN-EN 10049:2014-03 standard (Measurement of roughness average Ra and peak count RPc on metallic flat products) by the Diavite DH5 profilometer.

\section{RESULTS AND DISCUSSION}

The result of time influence the soaking the S235JR carbon structural steel in animal slurry at temperature $318 \mathrm{~K}$ on the relative mass loss (RML) with determination coefficient is presented in Figure 1. The course of relative mass loss is well expressed in the exponential curve. With increasing soaking time, a progressive increase in the corrosive wear of steel was noted. This can be explained by systematic development of the surface of the tested steel. Thus, the impact of animal slurry with similar intensity on a larger surface causes an increase in the weight loss of steel. These assumptions confirm the results test the roughness parameters of S235JR steel for different corrosion time with determination coefficient is presented in (Figure 2) for Ra and Rq and in (Figure 3) for Rt and Rp.

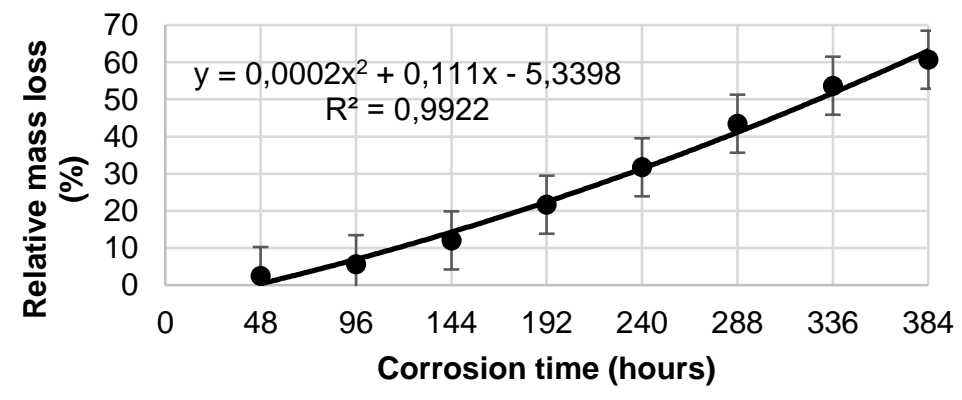

Figure 1 Percentage effects of corrosion time on the relative mass loss (RML) of S235JR carbon steel after corrosion tests in animal slurry at temperature $318 \mathrm{~K}$

The effect of corrosion time on the corrosion rate measured in $\mathrm{mm}$ per year of S235JR steel after corrosion tests in animal slurry at temperature $318 \mathrm{~K}$ with determination coefficient is presented in (Figure 4). The effect of corrosion time on the corrosion rate measured in gram per $\mathrm{m}^{2}$ of S235JR steel after corrosiontests in animal slurry at temperature $303 \mathrm{~K}$ with determination coefficient is presented in (Figure 5). 
Analyzing the corrosion rate determined both in $\mathrm{mm}$ per year (Figure 4) as well as gram per $\mathrm{m}^{2}$ (Figure 5), similar as in paper $[28,29]$, different angles of the curve were observed. It was depended on the time of steel soaking in animal slurry at temperature $318 \mathrm{~K}$.

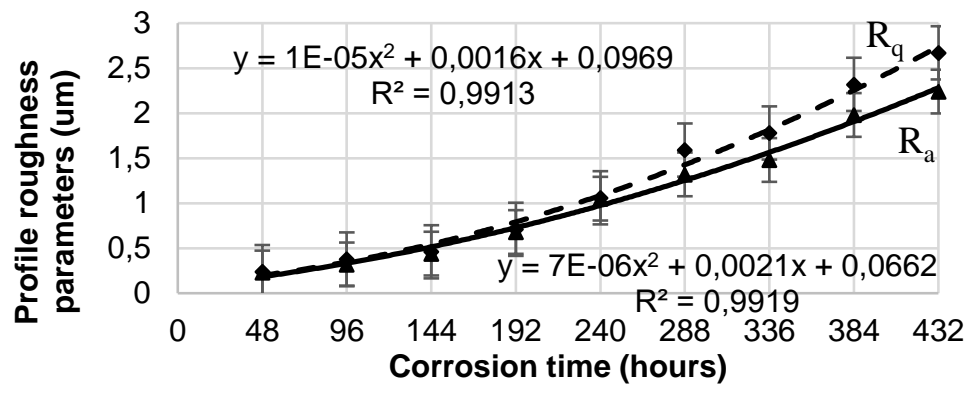

Figure 2 Profile roughness of S235JR carbon steel after corrosion tests in animal slurry at temperature 318 $\mathrm{K}$ for different corrosion time: $\mathrm{Ra}$ - arithmetical mean roughness value $(\mu \mathrm{m}) ; \mathrm{Rq}$ - mean peak width $(\mu \mathrm{m})$



Figure 3 Profile roughness of S235JR carbon steel after corrosion tests in animal slurry at temperature $318 \mathrm{~K}$ for different corrosion time: $\mathrm{Rp}$ - maximum roughness depth $(\mu \mathrm{m})$; Rt - total height of the roughness profile $(\mu \mathrm{m})$

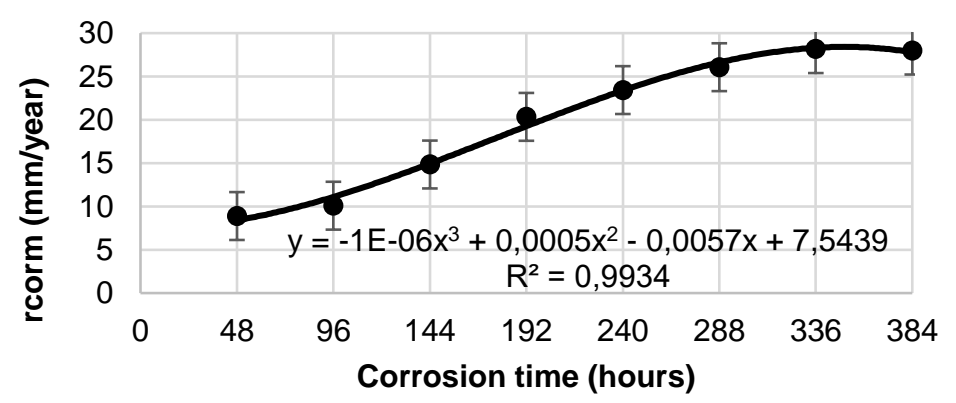

Figure 4 The effect of corrosion time on the corrosion rate measured in mm per year of S235JR carbon steel after corrosion tests in animal slurry at temperature $318 \mathrm{~K}$

A slight increase in corrosion rate was observed during the first 96 hours. After extending the time, the corossion rate increased intensively. After soaking more than 240 hours in an aggressive environment, the corrosion rate began to slow down. This nature of changes can be explained by the slow formation of steel surface development in the first period of tested S235JR carbon steel. Then the rapid development of corrosion was caused by the rapid progressive increase of the contact surface of the aggressive environment with steel in the second period. In the third soaking period of steel tested, the corrosion rate stabilizes (Figures 4 and 5), but the mass loss continues to increase exponentially (Figure 1). 


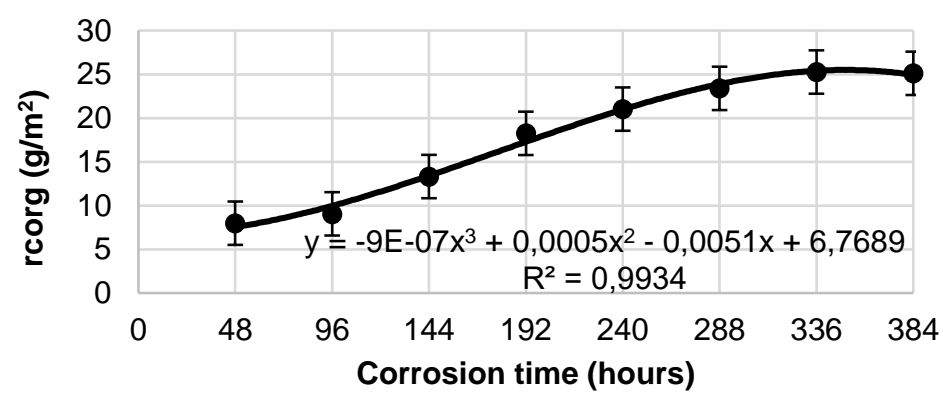

Figure 5 The effect of corrosion time on the corrosion rate measured in gram per $\mathrm{m}^{2}$ of S235JR carbon steel after corrosion tests in animal slurry at temperature $318 \mathrm{~K}$

\section{CONCLUSION}

In the study of the steel corrosion process, for a better presentation of its course one should present both the result of time the soaking the S235JR carbon structural steel in animal slurry on the relative mass loss as well as corrosion rate.

Corrosion rate equations, despite their inclusion in the standard for stainless steel, give good sense also for carbon steel. To better present the course of corrosion over time, the percentage corrosion loss and corrosion rate should be given simultaneously. The animal slurry environment is very aggressive and acid-proof steel should be used for equipment working in contact with it.

\section{REFERENCES}

[1] LU, B.T., LU, J.F. and LUO, J.L. Erosion-corrosion of carbon steel in simulated tailing slurries. Corr. Sci. 2011. vol. 53, pp. 1000-1008.

[2] MAHDI, E., RAUF, A. and ELTAI, E.O. Effect of temperature and erosion on pitting corrosion of X100 steel in aqueous silica slurries containing bicarbonate and chloride content. Corr. Sci. 2014. vol. 83, pp. 48-58.

[3] DE BELIE, N., SONCK, B., BRAAM, C.R., LENEHAND, J.J., SVENNERSTEDTE, B. and RICHARDSON, M. Durability of building materials and components in the agricultural environment, part II: Metal structures. Journal of Agricultural Engineering Research. 2000. vol. 75, pp. 333-347.

[4] LIPINSKI T. Corrosion resistance of 1.4362 steel in boiling 65\% nitric acid. Manufacturing Technology. 2016. vol. 16, pp. 1004-1009.

[5] AGUIRRE, J. and WALCZAK, M. Effect of dissolved copper ions on erosion-corrosion synergy of X65 steel in simulated copper tailing slurry. Tribology International. 2017. vol. 114, pp. 329-336.

[6] SONG, F. G. and DU, L.G. Erosion corrosion of low-alloy wear-resistant steels in alkaline slurry. Journal of Iron and Steel Research International. 2017. vol. 24, pp. 1065-1072.

[7] TANG, X., XU, L.Y. and CHENG, Y.F. Electrochemical corrosion behavior of X-65 steel in the simulated oil-sand slurry. II: Synergism of erosion and corrosion. Corr. Sci. 2008. vol. 50, pp. 1469-1474.

[8] UHLIG, H.H. and REVIE, R.W. Corrosion and corrosion control. $3^{\text {rd }}$ Edition, John Wiley and Sons 1985.

[9] YANG, Y. and CHENG, Y.F. Parametric effects on the erosion-corrosion rate and mechanism of carbon steel pipes in oil sands slurry. Wear. 2012. vol. 276-277, pp. 141-148.

[10] SZATANIAK, P., NOVY, F. and ULEWICZ, R. HSLA steels - comparison of cutting techniques. In METAL 2014:

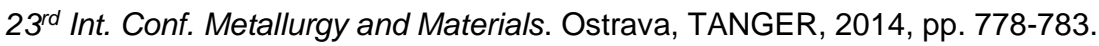

[11] KLIMECKA-TATAR, D. Powder Surface Modification as a Method of Corrosion Rate Limitation of the Magnetic RE-M-B Composite in an Acid Medium with Different pH. Materials Research Proc. 2018. vol. 5, pp.231-236.

[12] LIPINSKI, T. and KARPISZ, D. Corrosion rate of 1.4152 stainless steel in a hot nitrate acid. In METAL 2019: 28 $8^{\text {th }}$ Int. Conf. Metallurgy and Materials. Ostrava, TANGER, 2019, pp. 1086-1091. 
[13] SKRZYPCZAK, L., SKRZYPCZAK-PIETRASZEK, E., LAMER-ZARAWSKA, E. and HOJDEN, B. Micropropagation of Oenothera-Biennis L. and an Assay of Fatty-Acids. Acta Soc. Bot. Pol. 1994. vol. 63, pp. 173-177.

[14] SKRZYPCZAK-PIETRASZEK, E., KWIECIEN, I., GOLDYN, A. and PIETRASZEK, J. HPLC-DAD analysis of arbutin produced from hydroquinone in a biotransformation process in Origanum majorana L. shoot culture. Phytochemistry Letters. 2017, vol. 20, pp. 443-448.

[15] SKRZYPCZAK-PIETRASZEK, E., PISKA, K. and PIETRASZEK, J. Enhanced production of the pharmaceutically important polyphenolic compounds in Vitex agnus castus L. shoot cultures by precursor feeding strategy. Engineering in Life Sciences. 2018. vol. 18, pp.287-297.

[16] BROZOVA, S. INGALDI, M. and SPERLIN, I. Economical aspects of high-temperature heating utilization for industrial waste treatment. In METAL 2013: 22nd Int. Conf. on Metallurgy and Materials. Ostrava, TANGER, 2013, pp. 1735-1739.

[17] DZIUBA, S.T. and INGALDI, M. Segragation and recycling of packaging waste by individual consumers in Poland. In 15th Int. Multidisciplinary Scientific Geoconf. (SGEM), vol. III. Albena: Bulgarian Acad. Sci., 2015, pp.545-552.

[18] GADEK-MOSZCZAK, A. and WOJNAR, L. Objective, quantitative and automatic $x$-ray image analysis of the bone regenerate in the llizarov method. In ECS10: The $10^{\text {th }}$ European Congress of Stereology and Image Analysis. Milan: ISS, 2009, pp.453-458.

[19] GADEK-MOSZCZAK, A., RADEK, N., WRONSKI, S. and TARASIUK, J. Application the 3D Image Analysis Techniques for Assessment the Quality of Material Surface Layer Before and After Laser Treatment. Advanced Materials Research-Switz. 2014. vol.874, pp.133-138.

[20] WOJNAR, L., GADEK-MOSZCZAK, A. and PIETRASZEK, J. On the role of histomorphometric (stereological) microstructure parameters in the prediction of vertebrae compression strength. Image Analysis and Stereology. 2019, vol. 38, pp.63-73.

[21] STYRYLSKA, T. and PIETRASZEK, J. Numerical modeling of non-steady-state temperature-fields with supplementary data. ZAMM-Z. Angew. Math. Mech. 1992. vol. 72, pp. T537-T539.

[22] PIETRASZEK, J. Response surface methodology at irregular grids based on Voronoi scheme with neural network approximator. In: Rutkowski L., Kacprzyk J. (eds) Neural Networks and Soft Computing. Advances in Soft Computing, vol 19. Physica, Heidelberg: 2003, pp. 250-255.

[23] PIETRASZEK, J. Fuzzy Regression Compared to Classical Experimental Design in the Case of Flywheel Assembly. In: Rutkowski L., Korytkowski M., Scherer R., Tadeusiewicz R., Zadeh L.A., Zurada J.M. (eds) Artificial Intelligence and Soft Computing ICAISC 2012. Lecture Notes in Computer Science, vol 7267. Berlin, Heidelberg: Springer, 2012, pp. 310-317.

[24] GADEK-MOSZCZAK, A., PIETASZEK, J., JASIEWICZ, B., SIKORSKA, S. and WOJNAR, L. The Bootstrap Approach to the Comparison of Two Methods Applied to the Evaluation of the Growth Index in the Analysis of the Digital X-ray Image of a Bone Regenerate. New Trends in Comp. Collective Intell. 2015. vol. 572, pp.127-136.

[25] PIETRASZEK, J., KOLOMYCKI, M., SZCZOTOK, A. and DWORNICKA, R. The Fuzzy Approach to Assessment of ANOVA Results. Lecture Notes in Artificial Intelligence. 2016, vol. 9875, pp. 260-268.

[26] GAWLIK, J., KIELBUS, A. and KARPISZ, D. Application of an integrated database system for processing difficult materials. Solid State Phenomena. 2015. vol. 223, pp. 35-45.

[27] MALINDZAK, D., PACANA, A. and PACAIOVA, H. An effective model for the quality of logistics and improvement of environmental protection in a cement plant. Przemys/ Chemiczny. 2017. vol. 96, pp. 1958-1962.

[28] LIPINSKI, T. and KARPISZ, D. Effect of animal slurry on carbon structural s235jr steel at $303 \mathrm{~K}$. Engineering for Rural Development. 2020. vol. 19, pp. 1482-1487.

[29] LIPINSKI T. Corrosion effect of $20 \% \mathrm{NaCl}$ solution on basic carbon structural S235JR steel. In Proc. $15^{\text {th }}$ Int. Sci. Conf. Eng. for Rural Dev., Jelgava, 24-26.05.2017. 2017. vol. 15, pp. 1069-1074. 